\title{
Methane paradox in tropical lakes? Sedimentary fluxes rather than water column production in oxic waters sustain methanotrophy and emissions to the atmosphere
}

Cédric Morana $^{1,2 *}$, Steven Bouillon ${ }^{1}$, Vimac Nolla-Ardèvol ${ }^{1}$, Fleur A.E. Roland ${ }^{2}$, William Okello $^{3}$, Jean-Pierre Descy ${ }^{2}$, Angela Nankabirwa ${ }^{3}$, Erina $\mathrm{Nabafu}^{3}$, Dirk Springael ${ }^{1}$, Alberto V. Borges $^{2}$.

${ }^{1}$ Department of Earth \& Environmental Sciences, KU Leuven, Belgium

${ }^{2}$ Chemical Oceanography Unit, Université de Liège, Belgium

${ }^{3}$ Limnology Unit, National Fisheries Resources Research Institute, Uganda

Correspondence to: Cédric Morana (Cedric.Morana@kuleuven.be) 
Supplementary table and figures.

Table S1. Summary of major limnological characteristics of the sampled lakes. Numbers between brackets are the mean depth; numbers followed by an asterisk are the average value for two sampling cruises. $\mathrm{Zm}$ is the mixed layer depth and $\mathrm{Ze}$ is the euphotic zone depth.

\begin{tabular}{llllllc}
\hline \hline Lake & Mixing regime & $\begin{array}{l}\text { Surface area } \\
\left(\mathrm{km}^{2}\right)\end{array}$ & $\begin{array}{l}\text { Max depth } \\
(\mathrm{m})\end{array}$ & Zm (m) & Ze (m) & $\begin{array}{l}\text { Chlorophyll a } \\
\left(\mathrm{mg} \mathrm{m}^{-3}\right)\end{array}$ \\
\hline Edward & Monomictic & 2300 & $117(34)$ & $15^{*}$ & $7.7^{*}$ & $4.8^{*}$ \\
Kyamwinga & Monomictic & 2.6 & 40 & 5 & 3.1 & 6.0 \\
Nyamusingere & Polymictic & 3.84 & 3 & 0.5 & 1.1 & 88.3 \\
Katinda & Monomictic & 0.44 & 20 & $1^{*}$ & $1.2^{*}$ & $77.2^{*}$ \\
George & Polymictic & 250 & $7(3)$ & $0.15^{*}$ & $1.1^{*}$ & $149.7^{*}$ \\
\hline \hline
\end{tabular}



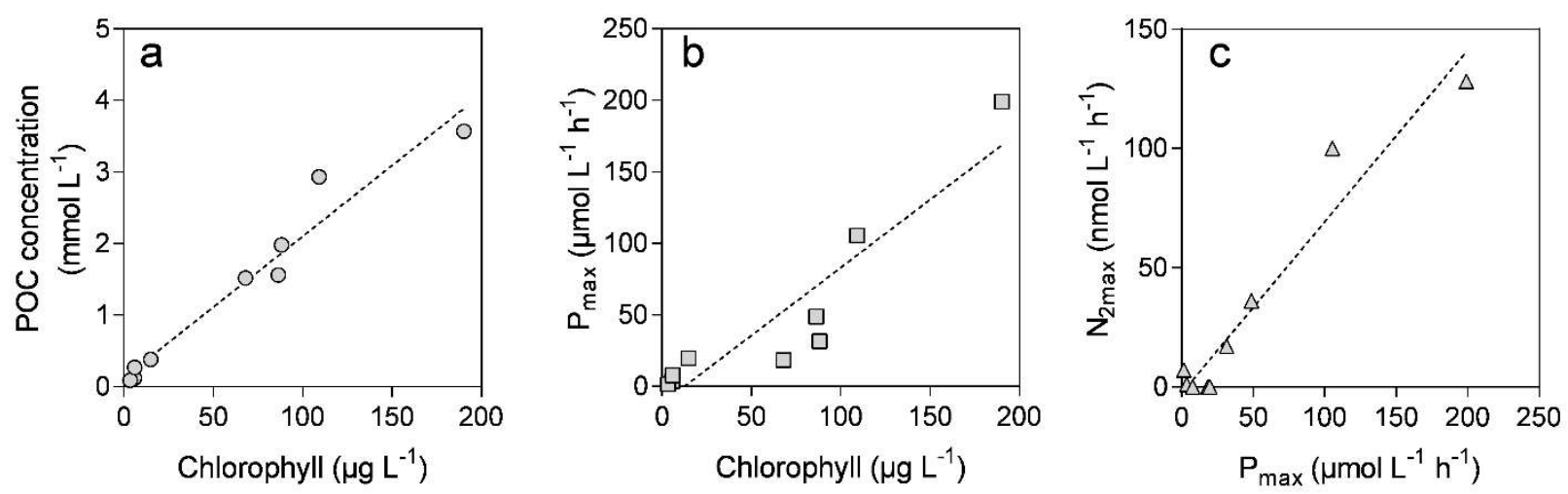

Figure S1. Relationships between phytoplankton primary production and $\mathbf{N}_{\mathbf{2}}$ fixation. Linear relationship between (a) the chlorophyll $a$ ( $\mu \mathrm{g}$ chla $\mathrm{L}^{-1}$ ) and particulate organic carbon (POC, mmol L-1) concentrations, (b) chlorophyll a and maximum photosynthetic activity (Pmax, mmol C L ${ }^{-1} \mathrm{~h}^{-1}$ ), and (c) Pmax and the maximum $\mathrm{N}_{2}$ fixation $\left(\mathrm{N}_{2} \mathrm{max}, \mathrm{nmol} \mathrm{N}_{2} \mathrm{~L}^{-1} \mathrm{~h}^{-1}\right)$ rates. 


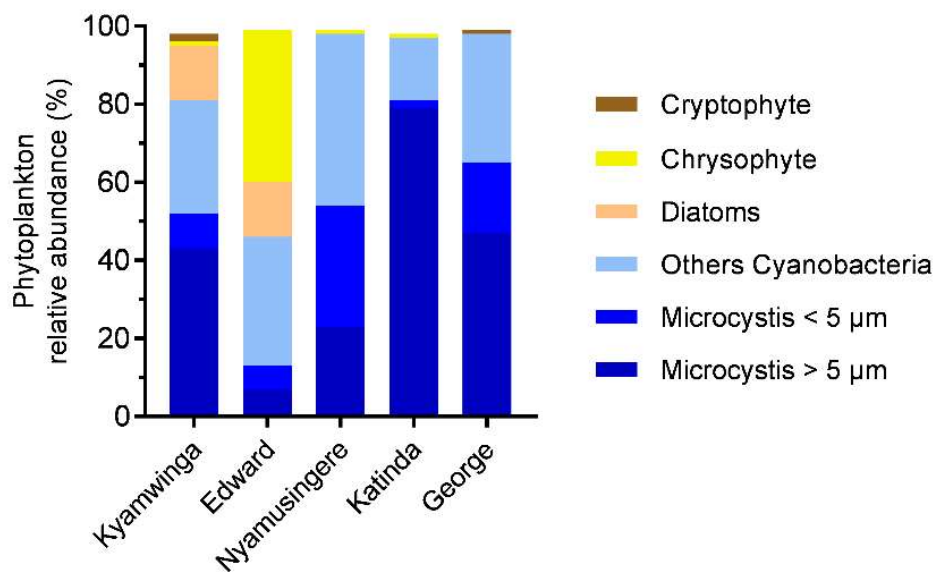

Figure S2. Phytoplankton community composition. Phytoplankton community composition in the surface waters the African lakes sampled. 


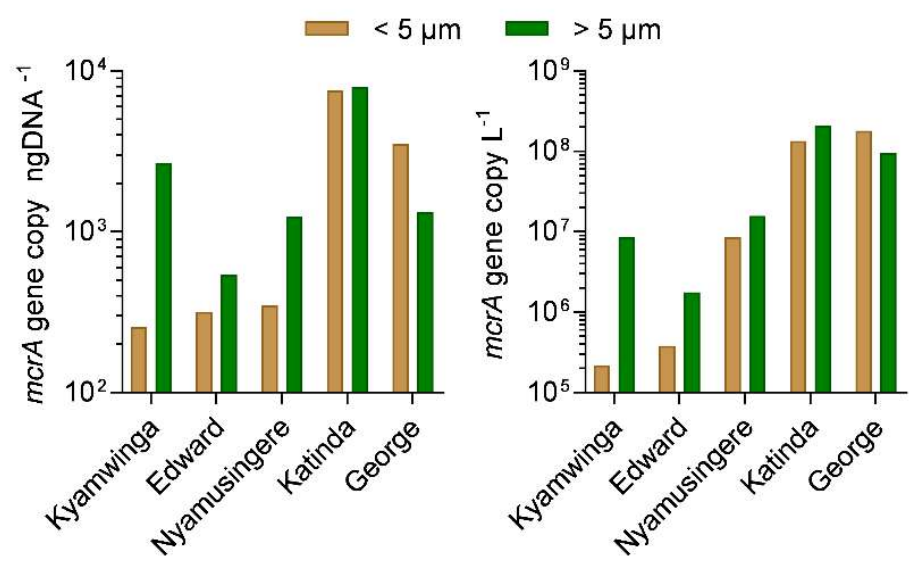

Figure S3. $\boldsymbol{m} \boldsymbol{c r A}$ gene abundance. $m c r A$ gene copy concentration (a) and $m c r A$ gene copy abundance normalized on the DNA concentration (b) in each African lake sampled. Green and brown bars represent the $>5 \mu \mathrm{m}$ and $<5$ $\mu \mathrm{m}$ fraction of the seston, respectively. 


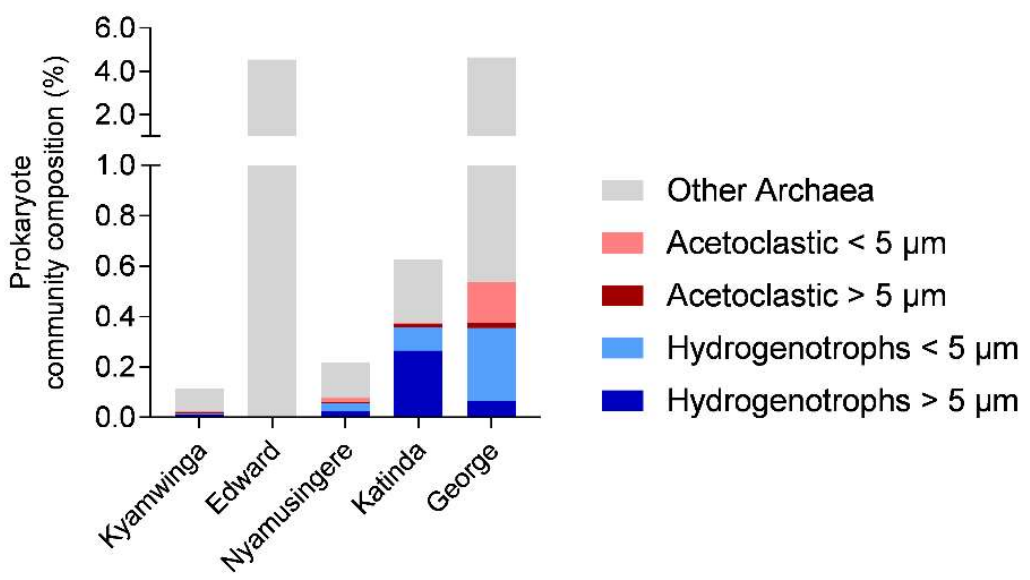

Figure S4. Prokaryote community composition. Contribution of methanogens to the prokaryote community composition in the African lake sampled. 

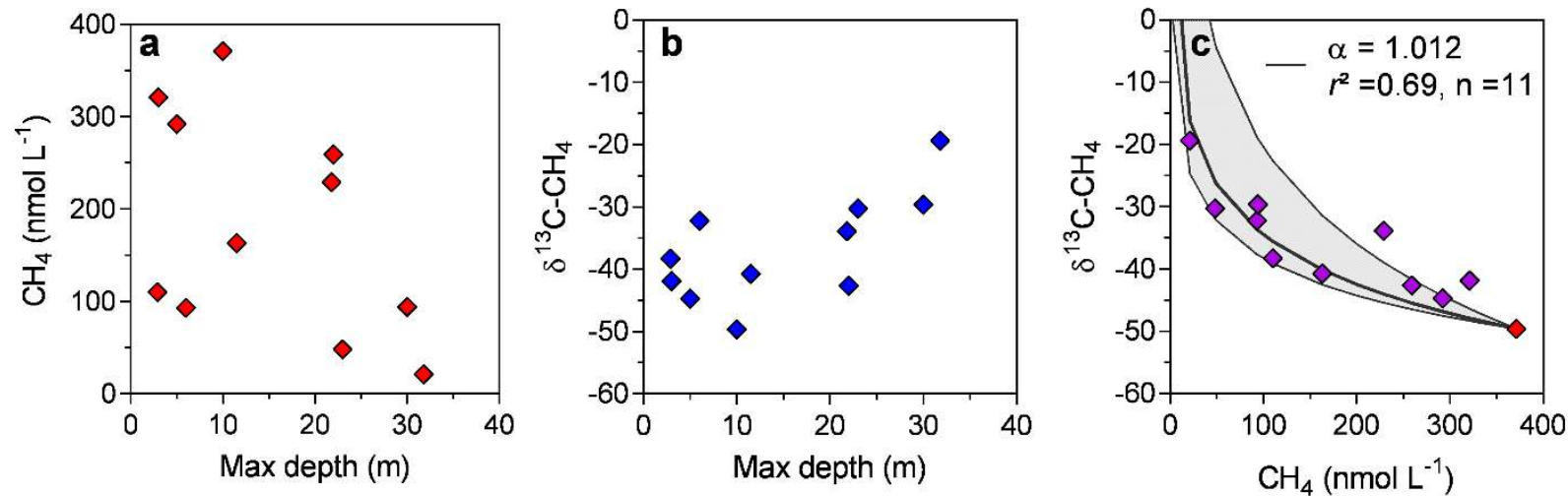

Figure S5. Littoral pelagic - gradient in L. Edward. Relationship between the maximum depth of the station and (a) the $\mathrm{CH}_{4}$ concentration ( $\left.\mathrm{nmol} \mathrm{L}-1\right)$ and (b) the stable carbon isotope composition of $\mathrm{CH}_{4}\left(\delta^{13} \mathrm{C}_{-} \mathrm{CH}_{4}, \%\right.$ ) in surface waters $(0.3 \mathrm{~m})$, in L. Edward. Data were collected between 18/01/2018 and the 24/01/2018. (c) Relationship between the $\mathrm{CH}_{4}$ concentration and the $\delta^{13} \mathrm{C}_{-} \mathrm{CH}_{4}$ in surface waters of $\mathrm{L}$. Edward. The black curve represents the fitted $\left(r^{2} 0.69, \mathrm{n}=11\right)$ apparent carbon isotope fractionation factor during $\mathrm{CH}_{4}$ oxidation $(\alpha)$ calculated as in Morana et al. (2015). Grey zone represents the expected $\delta^{13} \mathrm{C}_{-} \mathrm{CH}_{4}$ at a given concentration considering a range of $\alpha$ value comprised between 1.009 and 1.023 and a littoral (2.5 m max depth) surface water $\delta^{13} \mathrm{C}_{-} \mathrm{CH}_{4}$ source of $-43.6 \%$ (red symbol). The apparent $\mathrm{C}$ isotope fractionation $(\alpha=1.012)$ in L. Edward surface waters was close to the isotope fractionation factor previously determined experimentally for $\mathrm{CH}_{4}$ oxidation in $\mathrm{L}$. Kivu $(\alpha=1.016)$, another large East African lake (Morana et al. 2015). 


\section{$\mathrm{NaH}^{13} \mathrm{CO}_{3}(5 \%$ excess $)$}
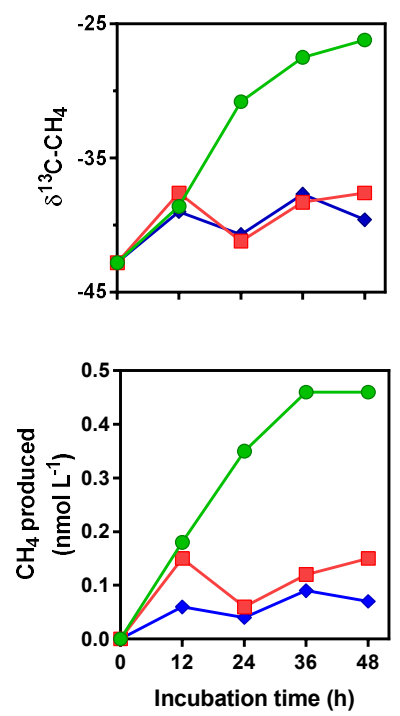

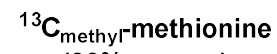

(99\% excess)
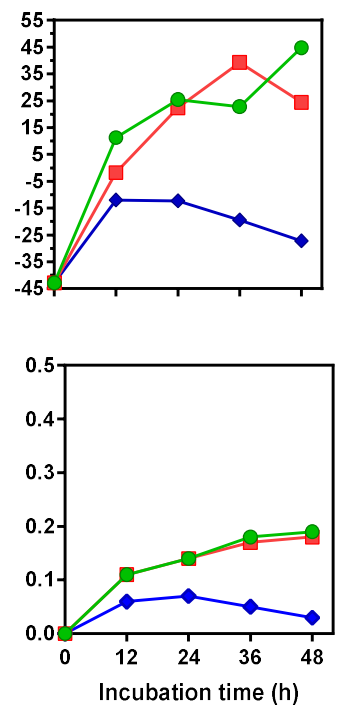

${ }^{13} \mathrm{C}_{1,2}$-acetate

(99\% excess)
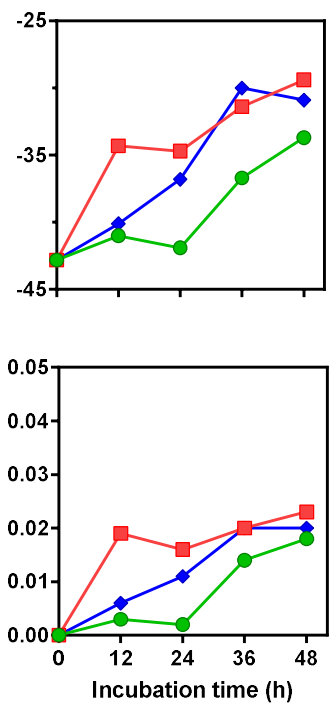

Control

(without ${ }^{13} \mathrm{C}$ tracer)

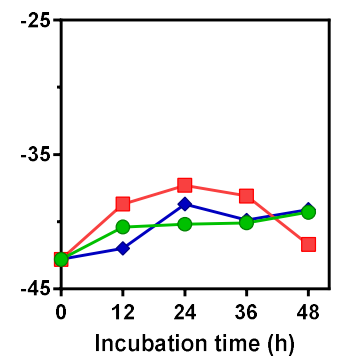

- Light

$\rightarrow$ Light + DCMU

$\leftrightarrow$ Dark

Figure S6. ${ }^{13} \mathrm{C}$ labelling experiment kinetics. Upper panel: In well-oxygenated surface waters of Lake Edward, evolution of the $\delta^{13} \mathrm{C}_{-} \mathrm{CH}_{4}$ during the incubation in bottles amended with $1 \mathrm{ml}$ of $\mathrm{NaH}^{13} \mathrm{CO}_{3}$ (leftmost), ${ }^{13} \mathrm{C}_{\text {methyl- }}$ methionine, ${ }^{13} \mathrm{C}_{(1,2)}$-acetate, or water (control treatment, rightmost). Note the difference in the amount of excess ${ }^{13} \mathrm{C}$ between the $\mathrm{NaH}^{13} \mathrm{CO}_{3}$ and the ${ }^{13} \mathrm{C}_{\text {methyl }}$-methionine and ${ }^{13} \mathrm{C}_{(1,2)}$-acetate treatment. Bottom panel: Amount of $\mathrm{CH}_{4}$ produced from the corresponding $13 \mathrm{C}$-tracer calculated at each time step as described in the material \& methods section. Green, grey and black symbols represent bottles incubated under light, light and DCMU, and darkness, respectively. $\mathrm{CH} 4$ concentration $\&{ }^{13} \mathrm{C}$ kinetics showed similar patterns in L. George, L. Katinda and L. Nyamusingere (not showed). 


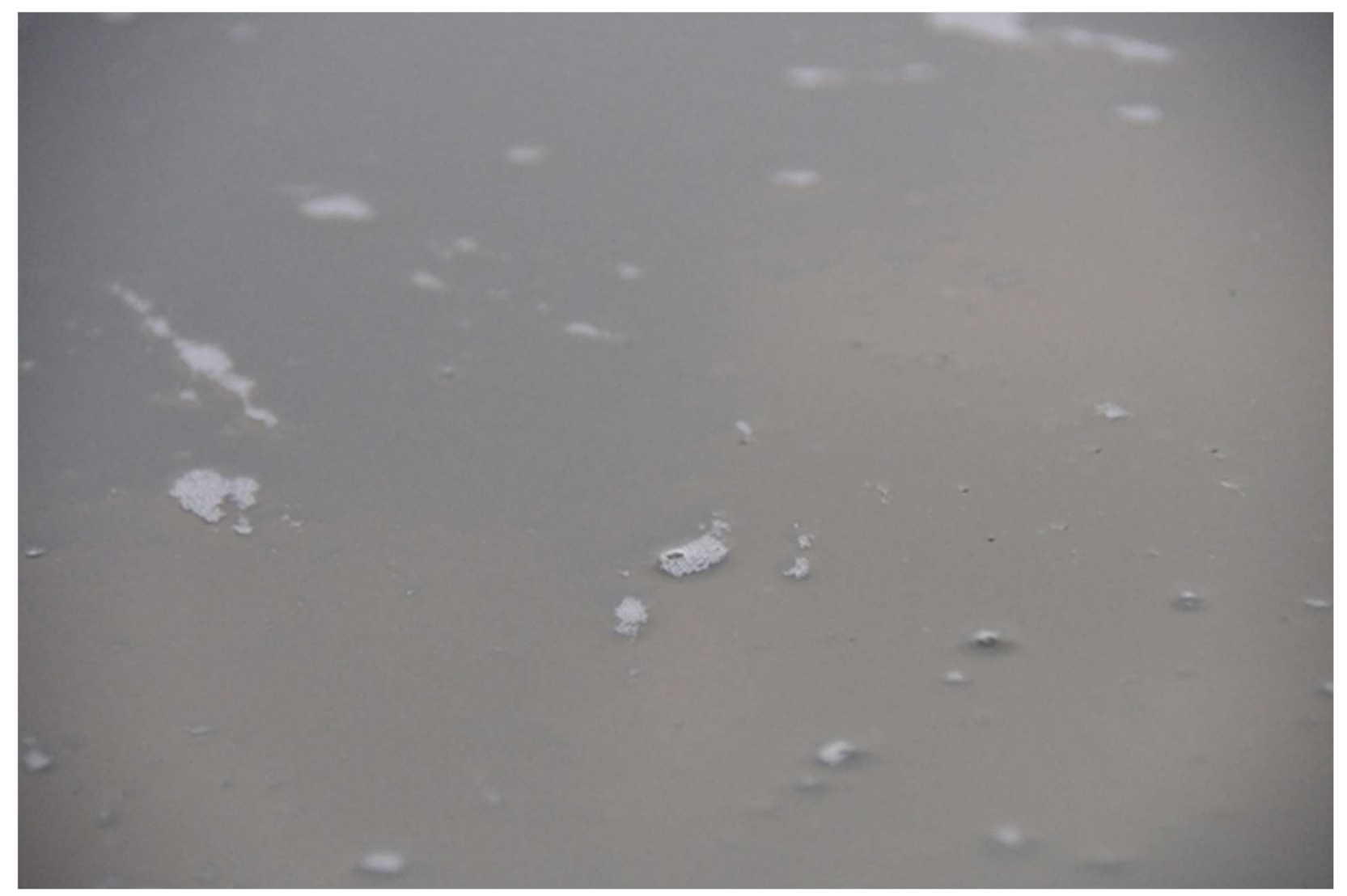

Figure S7. Ebullition in L. George. Picture showing stable bubbles trapped in the organic-rich surface waters of L. George a day of calm weather (28/01/18, sampling at noon). 